\title{
The Research to Practice Gap in Child Safety
}

Citation for published version (APA):

Scholtes, B. (2018). The Research to Practice Gap in Child Safety: Tools to Promote the Implementation of Evidence-Based Practice in Europe. [Doctoral Thesis, Maastricht University]. Gildeprint Drukkerijen. https://doi.org/10.26481/dis.20180425bs

Document status and date:

Published: 01/01/2018

DOI:

$10.26481 /$ dis.20180425bs

Document Version:

Publisher's PDF, also known as Version of record

\section{Please check the document version of this publication:}

- A submitted manuscript is the version of the article upon submission and before peer-review. There can be important differences between the submitted version and the official published version of record.

People interested in the research are advised to contact the author for the final version of the publication, or visit the DOI to the publisher's website.

- The final author version and the galley proof are versions of the publication after peer review.

- The final published version features the final layout of the paper including the volume, issue and page numbers.

Link to publication

\footnotetext{
General rights rights.

- You may freely distribute the URL identifying the publication in the public portal. please follow below link for the End User Agreement:

www.umlib.nl/taverne-license

Take down policy

If you believe that this document breaches copyright please contact us at:

repository@maastrichtuniversity.nl

providing details and we will investigate your claim.
}

Copyright and moral rights for the publications made accessible in the public portal are retained by the authors and/or other copyright owners and it is a condition of accessing publications that users recognise and abide by the legal requirements associated with these

- Users may download and print one copy of any publication from the public portal for the purpose of private study or research.

- You may not further distribute the material or use it for any profit-making activity or commercial gain

If the publication is distributed under the terms of Article $25 \mathrm{fa}$ of the Dutch Copyright Act, indicated by the "Taverne" license above, 
Summary 


\section{Introduction}

Although average injury rates are decreasing, large inequalities continue to exist between countries within the European Union. Mortality rates from injury for children aged 0 - 19 in Lithuania in 2014 were 19/100,000 whereas in Spain the rate was $4 / 100,000$. Within countries the picture is mixed and children's injury risk is related to factors such as their socio-economic status, the education level and employment status of their parents. The impact of these factors means that important inequalities exist.

Better prevention of child injury is thus needed to address inequalities; however, it is a multi-sectoral undertaking. Risk factors transcend generations and are multifaceted: social; environmental and economic. This complexity has led many to describe child injury as a wicked problem - a problem for which there is no single solution, and efforts to solve an aspect of the problem can lead to further complications and challenges. Responsibility for addressing risk factors transcends traditional policy sectors. Action also occurs at multiple levels of governance; from local action to initiatives at international (European or global) level. Furthermore, injury prevention requires participation from the public and private sector and from civil society.

This dissertation explores the space between research and practice, focussing upon facilitating positive action by stakeholders to address injury among children in Europe. The objectives of the research are to explore the facilitators and barriers during the implementation process, to identify the different policy sectors implicated in child safety, to assess potential ethical considerations and finally to provide tools to help policy makers to assess their local situation and find solutions.

\section{Method}

The dissertation focuses on four domains of child injury: road; water and home safety and intentional injury prevention. Data collection for chapters three, four and six occurred between 2011 and 2014 within the framework of the EU funded project; 'Tools to Address Childhood Trauma and Children's Safety' (TACTICS). Participants were also involved in the TACTICS project and came from 27 countries of the WHO European Region. Chapters two and five are based on literature reviews conducted outside the framework of the TACTICS project. 
The theoretical underpinning of the dissertation is based first: upon the Public Health Approach to injury prevention from Sleet et al, that underlines the importance of both an evidence-based approach and evidence-based practice within injury prevention. Second: the governance for health framework by Kickbusch and Gleicher which proposes the whole-of-government and whole-of-society approach to effective health governance. Third: the six stages of implementation proposed by Fixsen et al. theoretically guides the process of implementation.

A combination of research methods was used throughout. Literature reviews guided the direction of the dissertation and informed the content of the models and tools proposed. Quantitative and qualitative data was generated to identify the different sectors implicated in child injury prevention. A public health ethical framework was applied to an existing child safety intervention to explore ethical considerations. Finally, qualitative data was analysed using thematic content-analysis to explore the process of implementation.

\section{Results}

A practical tool for use at the local level to address the cross-cutting nature of child injury prevention was developed. The tool is based on Haddon's matrix and takes a life-course approach to injury prevention. It was developed for use by multi-sector stakeholders at the local level to better understand the complexity of child injury and develop multi-sectoral solutions.

Twenty-seven different policy sectors were found to be implicated in child safety. Of these 27 sectors nine sectors were identified as 'core' sectors:

Education;

Health;

Home Affairs;

Justice;

Media;

Recreation;

Research;

Social/Welfare Services and

Consumers 
Core sectors were considered applicable across the four domains of child safety studied.

Child safety reference frameworks (CSRF) were developed for use at the sub-national level. CSRF, can be used to inform policy makers about possible evidence-based child safety interventions, to assess the state of affairs in the region and to compare the situation regionally, nationally, internationally or over time.

An ethical assessment of an intervention for child safety in the home highlights the relevance of public health ethics to child safety interventions.

A thematic content analysis of facilitators and barriers for the adoption, implementation and monitoring of child safety interventions resulted in the identification of eight themes found to be applicable, to varying degrees throughout the three phases of the process.:

Management and collaboration;

Resources;

Leadership;

Nature of the intervention;

Political, social and cultural environment;

Visibility;

Nature of the injury problem and

Analysis and interpretation.

\section{Conclusion}

The findings demonstrate the multi-sectoral nature of child injury prevention and the challenges of implementation within an issue of such complexity. Despite the challenges, there is un-doubted scope for stakeholders at the local and regional levels to take positive action. There may be opportunities for different sectors to find crosssectoral co-benefits, within and outside the field of child injury prevention and beyond public health.

Future perspectives should embrace the multi-sectoral nature of injury prevention. Further research could focus upon a systematic analysis of potential co-benefits linked to injury prevention, to quantify the breadth of impact of individual interventions and incentivise their implementation across sectors. 